\title{
Muslim Milenial dan Gerakan Ekonomi Islam Indonesia
}

\author{
Nurhidayat ${ }^{1}$ \\ Universitas Muhammadiyah Jakarta \\ E-mail: nurhidayat@umj.ac.id \\ do https://doi.org/10.32507/mizan.v4i1.638
}

\begin{abstract}
The Islamic economic movement in Indonesia which has been running for more than 30 years has not yet found any significant results when viewed from the ratio of the number of Indonesian Muslims to Islamic financial institutions. Muslims still do not have the knowledge and awareness of the importance of the Islamic economy. The role and contribution of Muslims is still small in the Indonesian economic movement. This paper aims to provide an overview of the contribution of Indonesian millennial Muslims in the Islamic economic movement in Indonesia. The Islamic economic movement that began in 1991 is a movement that aims to educate and make Muslims aware of the importance of an economically compatible sharia. This movement cannot be separated from the role and contribution of Indonesian millennial Muslims. This paper concludes that the role of Indonesian millennial Muslims in the Islamic economic movement is very important their superiority in mastering technology so that when they work in Islamic financial institutions in addition they become their employees as well as marketing the Islamic economy which disseminates the importance of the Islamic economy. This role is also their contribution in the Islamic economic movement. They have fulfilled the needs of human resources in Islamic financial institutions in Indonesia.
\end{abstract}

Keywords: Millennial Muslims, Islamic Economic Movement, Indonesia

\begin{abstract}
Abstrak
Gerakan ekonomi Islam di Indonesia yang sudah berjalan kurang lebih 30 tahun belum, menemukan hasil yang signifikan jika dilihat dari rasio jumlah muslim Indonesia dengan lembaga keuangan syariah. Umat Islam masih belum memiliki pengetahuan dan kesadaran pentingnya ekonomi Islam. Peran dan kontribusi umat Islam masih kecil dalam gerakan ekonomi Indonesia. Tulisan ini bertujuan untuk memberikan gambaran tentang kontribusi muslim milenial Indonesia dalam gerakan ekonomi Islam di Indonesia. Gerakan ekonomi Islam yang dimulai sejak 1991 merupakan gerakan yang bertujuan mencerdaskan dan menyadarkan umat Islam akan pentingnya ekonomi yang sesuai dengan syariah. Gerakan ini tidak bisa dilepaskan dari peran dan kontribusi muslim milenial Indonesia. Tulisan ini berkesimpulan bahwa peran muslim milenial Indonesia dalam gerakan ekonomi Islam sangat penting keunggulan mereka menguasai teknologi sehingga ketika mereka bekerja di lembaga keuangan Islam selain mereka menjadi pegawai mereka juga sebagai marketing ekonomi Islam yang menyebarluaskan pentingnya ekonomi Islam. Peran tersebut juga menjadi kontribusi mereka dalam gerakan ekonomi Islam. Mereka telah memenuhi telah memenuhi kebutuhan sumber daya manusia di lembaga keuangan syariah di Indonesia.

Kata kunci: Muslim Milenial, Gerakan Ekonomi Islam, Indonesia
\end{abstract}

* Naskah diterima tanggal: 12 Januari 2020, direvisi: 11 Februari 2020, disetujui untuk terbit: 2 Maret 2020.

${ }^{1}$ Nurhidayat adalah Dosen tetap Fakultas Agama Islam, Universitas Muhammadiyah Jakarta. E-mail: nurhidayat@umj.ac.id. 


\section{A. PENDAHULUAN}

Sejak tahun 2015 struktur penduduk Indonesia mengalami bonus demografi. Tentunya hal ini tidak terlepas dari peran generasi milenial. Menurut data Badan Pusat Statistik (BPS) rasio ketergantungan Indonesia tahun 2015 sebesar 49,20 yang secara tidak langsung memiliki makna bahwa persentase jumlah penduduk usia produktif mencapai sekitar 67,02 persen dari jumlah penduduk keseluruhan. Persentase jumlah penduduk usia produktif ini dikaitkan dengan persentase generasi milenial tahun 2017 sebesar 33,75 persen dari jumlah penduduk keseluruhan. $^{2}$

Hal ini menunjukkan bahwa sumbangsih generasi milenial dalam membentuk struktur jumlah penduduk usia produktif tergolong cukup tinggi, karena sekitar 50,36 persen dari jumlah penduduk usia produktif pada dasarnya merupakan generasi milenial dengan asumsi rasio ketergantungan 2015 dan 2017 adalah sama besar. Generasi ini yang akan memegang kendali atas roda pembangunan khususnya di bidang perekonomian yang diharapkan akan mampu membawa bangsa Indonesia menuju ke arah pembangunan yang lebih maju dan dinamis.

Bonus demografi biasanya hanya dialami oleh negara berkembang, yang biasanya memiliki piramida kependudukan berjenis limas. Piramida kependudukan berbentuk limas ini menunjukan bahwa penduduk pada negara tersebut didominasi oleh bayi, anak-anak, dan remaja yang merupakan generasi penerus bangsa. Menurut Badan Keluarga Berencana Nasional (BKKBN), Indonesia akan mengalami bonus demografi pada rentang waktu antara 2020-2030. Pada saat itu jumlah usia angkatan kerja (15-64 tahun) mencapai sekitar 70 persen, sedangkan sisanya 30 persen merupakan penduduk yang tidak produktif. Persentase ini akan semakin ideal begitu memasuki masa puncak antara tahun 2028-2030. Setelah itu, komposisi mulai kembali menjauh dari persentase ideal. Oleh sebab itu, bonus demografi hanya terjadi sekali dalam sejarah perjalanan sebuah bangsa.

Jika mengacu pada data BPS tahun 2019, jumlah penduduk Indonesia tahun 2020 diproyeksikan mencapai 270 juta jiwa. Dari jumlah tersebut penduduk muslim berjumlah 229,62 juta jiwa. Dari jumlah tersebut sebanyak 66,07 juta jiwa usia 0-14 tahun dan usia 15-64 tahun berjumlah 185,34 juta jiwa. Tahun 2020 diperkirakan usia produktif 15-64 tahun sebesar 68,75 \%. Ini adalah kelompok potensial. Anak-anak muda (kaum milenial) ini memiliki peran dan kontribusi yang determinan. ${ }^{3}$

Oleh karena itu gerakan ekonomi Islam di Indonesia tidak bisa dilepaskan dari peran muslim milenial ini. Tulisan ini mencoba untuk menggambarkan tentang genealogi muslim milenial di Indonesia, serta karakteristik dan kontribusi muslim milenial Indonesia dalam gerakan ekonomi Islam di Indonesia.

2 Tim Kementerian Pemberdayaan Perempuan dan Perlindungan Anak Dengan Pusat Statistik. (2018). Statistik Gender Tematik: Profil Generasi Milenial Indonesia. Kementerian Pemberdayaan Perempuan dan Perlindungan Anak.

${ }^{3}$ Data dari BPS online diakses pada hari Senin, 20 Januari 2020. 


\section{Tinjauan Teori}

Ekonomi Islam sebagai ilmu pemikiran muslim yang bertujuan untuk menjawab berbagai tantangan ekonomi manusia sesuai dengan zamannya, dengan berdasarkan kepada panduan dari Allah dan Rasul-Nya yang termaktub di dalam AlQur'an dan Sunnah, yang dibantu dengan akal dan pengalaman untuk memahaminya. ${ }^{4}$

Secara umum, ekonomi Islam terbagi ke dalam tiga makna. Pertama, ekonomi Islam sebagai ilmu ekonomi yang berlandaskan kepada nilai-nilai ajaran Islam. Kedua, ekonomi Islam sebagai sistem yang menyangkut pengaturan kegiatan ekonomi dalam suatu masyarakat atau negara berdasarkan suatu cara atau metode tertentu. Ketiga, ekonomi Islam sebagai kegiatan perekonomian umat Islam. Ketiga makna tersebut merupakan tiga pilar yang harus membentuk sebuah sinergi. ${ }^{5}$

Dalam hukum positif yang aplikatif, ekonomi Islam dikategorikan sebagai sistem ekonomi yang sejalan dengan ekonomi Pancasila dan bersifat compatible walaupun tidak sepenuhnya substitutable. Untuk itu, ekonomi Islam tidak boleh direduksi hanya dengan memusatkan pada upaya membangun lembaga keuangan syariah. Akan tetapi ekonomi Islam harus dapat menangkal sistem ekonomi yang eksploitatif secara luas, yang memelihara dan menumbuhkan kesenjangan ekonomi yang membiarkan terjadinya trade off secara sistematik, yang subordinatif dan diskriminatif yang membiarkan perkembangan faham dan perilaku laisse $z$ faire. ${ }^{6}$

Beberapa pakar memberikan alasan bahwa dalam ajaran Islam, perilaku individu dan masyarakat dikendalikan untuk memenuhi kebutuhan dan menggunakan sumber daya yang ada. Dalam ajaran Islam ditegaskan bahwa sumber daya yang tersedia adalah berkecukupan dan karena itu, dengan kecakapannya, manusia dituntut untuk berupaya memakmurkan dunia dan upaya ini merupakan bentuk ibadah kepada Tuhan. Dengan demikian, ekonomi Islam merupakan ilmu dan sistem yang bertugas untuk memanfaatkan sumber daya yang tersedia dan berkecukupan itu dalam rangka memenuhi kebutuhan masyarakat dalam konteks kemaslahatan bersama. ${ }^{7}$

\section{B. METODE PENELITIAN}

Penelitian ini menggunakan pendekatan kualitatif untuk menjelaskan dan menganalisis tentang genealogi muslim milenial di Indonesia, termasuk karakteristik dan kontribusinya dalam gerakan ekonomi Islam di Indonesia.

Sumber data utama adalah referensi yang terkait dengan muslim milenial dan juga data-data yang bersumber dari BPS. Adapun pembahasan penelitian berbentuk

\footnotetext{
${ }^{4}$ Syed Nawab Haider Naqvi. (1985). Etika dan Ilmu Ekonomi: Suatu Sintesis Islami. Bandung: Mizan.

${ }^{5}$ M. Dawam Rahardjo. (1999). Islam dan Transformasi Sosial Ekonomi Jakarta: LSAF.

${ }^{6}$ Euis Amalia. (2008). Kadilan Distributif dalam Ekonomi Islam: Penguatan Peran LKM dan UKM di Indoensia. Jakarta: Rajagrafindo.

${ }^{7}$ MM. Metwally. (1995). Teori dan Model Ekonomi Islam. Jakarta: Bangkit Daya Insana.
} 
deskriptif. Tujuannya adalah untuk membuat deskripsi, atau gambaran, faktual dan akurat mengenai muslim milenial dan gerakan ekonomi Islam di Indonesia. ${ }^{8}$

\section{ANALISIS DAN PEMBAHASAN}

\section{Genealogi Muslim Milenial}

Istilah milenial dicetuskan pertama kali oleh William Strauss dan Neil dalam bukunya yang berjudul Millennials Rising: The Next Great Generation. Menurut keduanya kelompok generasi milenial adalah anak-anak yang lahir pada tahun 1982 dan masuk jenjang pendidikan pra-sekolah, mereka inilah yang terhubung dengan era milennium pada saat lulus SMA pada tahun $2000 .{ }^{9}$

Teori lain dikemukakan oleh Elwood Carlson dalam bukunya berjudul The Lucky Few: Between the Greatest Generation and the Baby Boom, menurutnya generasi milenial adalah mereka yang lahir dalam rentang tahun 1983 sampai dengan 2001. Jika didasarkan pada Generation Theory yang dicetuskan oleh Karl Mannheim pada tahun 1923, generasi milenial adalah generasi yang lahir pada rasio tahun 1980 sampai dengan 2000. Generasi milenial juga disebut sebagai generasi Y. Istilah ini mulai dikenal dan dipakai pada editorial koran besar Amerika Serikat pada Agustus 1993.10

Menurut proyeksi BPS, tahun 2020 adalah tahun dimulainya bonus demografi, generasi milenial berada pada rentang usia 20 tahun hingga 40 tahun. Usia tersebut adalah usia produktif yang akan menjadi tulang punggung perekonomian Indonesia. Tiga tahun menjelang era tersebut terjadi, jumlah generasi milenial sudah dominan dibandingkan generasi lainnya. Jumlah generasi milenial mencapai sekitar 88 juta jiwa atau 33,75 persen dari total penduduk Indonesia. Proporsi tersebut lebih besar dari proporsi generasi sebelumnya seperti generasi $X$ yang (25,74 persen) maupun generasi baby boom dan veteran (11,27 persen). Demikian juga dengan jumlah generasi $\mathrm{Z}$ baru mencapai sekitar 29,23 persen. ${ }^{11}$

Dari 88 juta jiwa generasi milenial diantaranya adalah muslim milenial. Muslim milenial ini merupakan generasi pertama dari kelas menengah muslim Indonesia. Sejak tahun 1970 kelas menengah muslim ini adalah anak-anak yang mendapatkan akses ilmu pendidikan yang baik, bahkan mereka berpendidikan S1, S2 dan S3 lulusan perguruan tinggi dalam maupun luar negeri. Pendidikan menjadi faktor determinan mobilitas intelektual, sosial dan ekonomi muslim milenial Indonesia. Melalui

${ }^{8}$ Moh. Nazir. (1998), Metode Penelitian. Jakarta : Ghalia Indonesia.

9 Tim Kementerian Pemberdayaan Perempuan dan Perlindungan Anak Dengan Pusat Statistik. (2018). Statistik Gender Tematik: Profil Generasi Milenial Indonesia. Kementerian Pemberdayaan Perempuan dan Perlindungan Anak.

10 Tim Kementerian Pemberdayaan Perempuan dan Perlindungan Anak Dengan Pusat Statistik. (2018). Statistik Gender Tematik: Profil Generasi Milenial Indonesia. Kementerian Pemberdayaan Perempuan dan Perlindungan Anak.

${ }^{11}$ https://www.bps.go.id/diakses 21.13 WIB 
pendidikan inilah mereka mendapatkan akses ilmu pengetahuan dan kompetensi tinggi. ${ }^{12}$

\section{Karakteristik Gerakan Ekonomi Islam Indonesia}

Gerakan ekonomi Islam di Indonesia sejak tiga puluh tahun lalu, belum menemukan hasil yang signifikan, jika dilihat dari rasio jumlah muslim Indonesia dengan lembaga keuangan syariah. Umat Islam masih belum memiliki pengetahuan dan kesadaran tentang pentingnya ekonomi syariah. Peran dan kontribusi umat Islam masih kecil dalam gerakan ekonomi Indonesia.

Gerakan ini dimulai dengan pendirian lembaga keuangan syariah memiliki tujuan utamanya adalah dakwah. Dakwah yang dimaksud adalah sebagai upaya alternatif penegakan syariah Islam di Indonesia. Setelah sebelumnya melalui pendekatan gerakan dakwah politik mengalami berbagai kegagalan. ${ }^{13}$

Tentunya hal ini menggerakan dan memperkuat tiga sektor, yakni sektor riil (bisnis dan perdagangan), zakat, infak dan sedekah (ZIS), dan sektor moneter (Lembaga Keuangan Syariah). Islam ajaran yang kaffah karena berfungsi sebagai agama dan dunia, ibadah dan muamalah, akidah dan syariah, kebudayaan dan peradaban, agama dan negara. Oleh sebab itu menurutnya Islam bukan hanya sekedar agama, terlebih lagi hanya sekedar identitas, akan tetapi Islam tampil dan berperan sebagai jalan hidup way of life. ${ }^{14}$

Pilar atau sub sistem yang pertama dari gerakan ekonomi Islam ini adalah sektor riil (usaha, perdagangan, atau bisnis), pilar pertama sangat penting, sebab sektor ini dapat menggerakan sekaligus meningkatkan kesejahteraan ekonomi umat. Dalam sejarah Rasulullah SAW merupakan pebisnis, sehingga Rasulullah SAW sangat mendorong penganutnya untuk berbisnis. Sub sistem yang kedua dari pilar ekonomi syariah adalah sektor zakat dan sektor voluntary lainnya, seperti infak atau sedekah dan wakaf. Zakat merupakan ibadah maaliyyah ijtima'iyyah yang dapat meningkatkan kesejahteraan. ${ }^{15}$

Gerakan ekonomi Islam melalui optimalisasi penghimpunan dan pendayagunaan zakat di Indonesia dinilai sangat potensial. Sebab Indonesia merupakan negara yang memiliki potensi zakat terbesar dibandingkan dengan negaranegara berpenduduk muslim lainnya. Berdasarkan laporan sebuah riset yang dilakukan oleh IRTI-IDB (Islamic Research and Training Institute Islamic Development Bank), dapat disimpulkan bahwa potensi zakat sama dengan 2\% dari GDP (Gross Domestic Product). Kalau GDP Indonesia tahun 2018 diasumsikan sebesar Rp 5.000

${ }^{12}$ Azyumardi, Azra. (2000). Pendidikan Islam Tradisi dan Modernisasi Menuju Milenium Baru. Jakarta: PT. Logos Wacana Ilmu.

${ }^{13}$ Dawam Raharjo. (1999). Islam dan Transformasi Sosial Ekonomi. Jakarta: LSAF.

${ }^{14}$ Greg, Faealy, \& Sally, White. (2008). Expressing Islam: religion life and politics in Indonesia Singapore: ISEAS Publishing Institute of Southeast Asian Studies.

15 Yusuf, Al-Qaradhawi. (2005). Spektrum Zakat Dalam Membangun Ekonomi Kerakyatan. Jakarta: Zikrul Hakim. 
trilyun. Maka potensi zakat di Indonesia 2\% dari GDP (Gross Domestic Product) sebesar Rp 1.000 trilyun sama dengan Rp 100 trilyun. ${ }^{16}$

Perkembangan perbankan syariah dalam kurun waktu kurang lebih dua puluh tahun terakhir telah di satu sisi menunjukkan kemajuan yang signifikan secara kuantitas perjalanan selama kurang lebih dua puluh tahun. Sejak dioperasikannya Bank Muamalat Indonesia (BMI) pada tanggal 1 Mei 1992 sampai tahun 2018 telah tercatat 14 Bank Umum Syariah (BUS), 24 Unit Usaha Syariah (UUS), 155 BPR Syariah dengan jumlah kantor kas 2.526 kantor. Dan sampai triwulan I tahun 2015 tercatat dana pihak ketiga sebesar Rp 75,085 milyar, pembiayaan Rp 71,449 milyar dan jumlah rekening $\operatorname{Rp} 1,14$ trilyun. ${ }^{17}$

Total aset perbankan syariah berdasarkan data dari Bank Indonesia per bulan Desember tahun 2015, jumlah aset perbankan syariah (BUS dan UUS) tercatat sebesar Rp 97,5 trilyun, sedangkan jumlah aset BPRS tercatat sebesar Rp 2,7 trilyun. Jadi total asset keseluruhan adalah sebesar Rp 100,2 trilyun. Data ini menunjukan telah terjadi kenaikan aset sekitar 31,9\% dibandingkan aset tahun 2014 lalu. Adapun jumlah sumber daya manusia pada bank syariah pada tahun 2015 berjumlah 51.864 orang.

Perkembangan lembaga keuangan syariah tersebut didukung oleh beberapa faktor, diantaranya adalah faktor internal yaitu perbaikan manajemen, sosialisasi dan pelayanan yang baik. Dan secara eksternal perkembangan perbankan syariah juga didukung oleh faktor politik dengan adanya regulasi dengan lahirnya Undang-undang Nomor 10 Tahun 1998 tentang perubahan undang-undang Nomor 7 Tahun 1992 yang mengakui keberadaan bank syariah dan bank konvensional serta memperkenankan bank konvensional membuka kantor cabang syariah.

Salah satu masalah yang dihadapi perbankan syariah saat ini adalah persoalan Sumber Daya Manusia (SDM). Jumlah SDM perbankan syariah sejak tahun 2011 sampai 2015 mengalami peningkatan. SDM perbankan syariah pada tahun 2015 berjumlah 61.429 orang. Dari jumlah tersebut hanya 10\% SDM perbankan syariah yang memiliki latar belakang ekonomi syariah, dan $90 \%$ berlatar belakang pendidikan ekonomi konvensional atau lulusan perguruan tinggi umum. ${ }^{18}$ Secara kuantitas industri perbankan syariah mengalami kekurangan SDM yang sesuai dengan tuntutan dan kebutuhan. Dan secara kualitas menyiapkan SDM yang profesional memang bukanlah persoalan yang mudah.

Pertumbuhan perbankan syariah tersebut disebabkan oleh beberapa faktor pendukung, diantaranya adalah faktor internal dari bank syariah itu sendiri melakukan perbaikan manajemen, sosialisasi dan pelayanan yang baik. Dan secara eksternal perkembangan perbankan syariah juga dukung politik dengan adanya Stories, IDB.

${ }^{16}$ Islamic Development Bank. (2016). Forging a Better Future, Togeher Selected recent Success

${ }_{17}$ Greg, Faealy, \& Sally, White. (2008). Expressing Islam: religion life and politics in Indonesia Singapore: ISEAS Publishing Institute of Southeast Asian Studies.

${ }^{18}$ Euis Amalia. (2010). Peta Potensi SDM Ekonomi Islam pada PTAI dan PTU Analisi Kurikulum, Model Pembelajaran dan Hubungannya dengan Kebutuhan SDM pada Industri Keuangan Syariah. IPIEF, Fakults Ekonomi UMY, Yogyakarta. 
regulasi dengan lahirnya Undang-undang Nomor 7 Tahun 1992 tentang perbankan yang mengakomodasi perbankan dengan prinsip bagi hasil baik bank umum maupun BPRS.

\section{Kontribusi Muslim Milenial dalam Gerakan Ekonomi Islam}

Secara kuantitas muslim milenial Indonesia merupakan penduduk potensial dalam memainkan peran penting perpolitikan nasional dan penentu arah masa depan bangsa. Peran determinasi politik milenial saat ini menunjukan beberapa generasi milenial menduduki jabatan-jabatan strategis politik. Milenial dipercaya masyarakat menjadi Walikota, Bupati, Gubernur dan bahkan menjadi menteri.

Berdasarkan data dari berbagai sumber terdapat 7 orang anggota DPR RI berusia di bawah 25 tahun antara lain Hillari Brigitta Lasut 23 tahun, Farah Putri Nahlia milenial berusia 23 tahun, Muhammad Rahul berusia 23 tahun, Fachri Pahlevi seoarang milenial berusia 23 tahun menjadi anggota DPRRI. Walikota termuda usia 26 tahun Muhammad Syahrial Walikota Tanjung Balai Sumatera Utara, Bupati milenial berusia 28 tahun di Trenggalek Jawa Timur, Emil Elistianto Dardak Wakil Gubernur Jawa Timur Andika Hazrumy Wakil Gubernur Banten 33 tahun. Syauqi Farhan Mawali anggota DPRD Kota Tangerang Selatan berusia 22 tahun, Putri Ayu Anisya berusai 24 tahun. Dan Nadiem Makarim Menteri Pendidikan Republik Indonesia berusia 35 tahun.

Jika dihubungkan dengan perkembangan dua dasawarsa terakhir, dengan munculnya lembaga keuangan syariah antara lain bank syariah, BMT, BPRS, Takaful, dan lembaga filantropi. Tidak diragukan lagi, lembaga-lembaga ini muncul dan berkembang berkat dukungan kekuatan ekonomi, sosial dan kultural kelas menengah muslim baru yang terus mengalami peningkatan semangat dan antusiasme keagamaan. Ini adalah ceruk pasar potensial bagi lembaga keuangan syariah di Indonesia yang harus dioptimalkan.

Salah satu ciri muslim milenial yaitu sadar akan pentingnya penguasaan teknologi (melek teknologi), sehingga promosi digital sangat efektif. Berdasarkan survei yang dilakukan oleh Asosiasi Penyelenggara Jasa Internet Indonesia (APJII) pada 2018 yaitu 171,18 juta jiwa (64,8\% dari total penduduk) adalah pengguna internet. Dan jika dilihat dari segi umur, maka pengguna internet dikuasai oleh generasi milenial (generasi yang lahir dari tahun 1980-2000).

Gerakan ekonomi Islam di Indonesia menurut teori mobilisasi sumber daya (resource mobilization theory) menekankan pentingnya diperlukan tindakan kolektif yang terorganisasi. Dalam konteks ini muslim milenial Indonesia merupakan kelompok yang terorganisasi dalam gerakan ekonomi Islam, mereka terpragmentasi dalam kelompok-kelompok seperti hijrah dan hijaber. Maka dibutuhkan pendekatan kepada kelompok tersebut.

Berdasarkan data dari Rumah.com Property Affordability Sentiment Index H2 2019, pembiayaan dengan KPR Syariah cenderung lebih diminati oleh kalangan muda 56 persen responden yang berusia 22-29 tahun dan 50 persen responden yang berusia 
30-39 tahun menyukai KPR Syariah dibandingkan KPR Konvensional. Ini adalah sebuah kesadaran positif yang muncul dikalangan muslim milenial. Dengan jumlah generasi milenial sejumlah 85 juta jiwa atau mencapai $34,45 \%$ dari total seluruh penduduk Indonesia, generasi milenial merupakan pasar yang memiliki potensi besar di tengah industri perbankan syariah. ${ }^{19}$

Faktan lain didukung oleh data yang dikeluarkan dari Kementerian Agama Republik Indonesia muslim milenial merupakan usia potensial dalam pengembangan zakat di Indonesia, dengan asumsi data yang digunakan adalah data Komisi Pemilihan Umum (KPU) yang menyebutkan bahwa kelompok milenial 70-80 juta. Jika dihitung potensi zakatnya, kita asumsikan saja sepersepuluh dari jumlah milenial tersebut yang beragama Islam dan mempunyai penghasilan melebihi nishab.

Jika rata-rata penghasilan mencapai $R p 4.200 .000$ per bulan, maka berjumlah $R p$ 50.400.000 per tahun. Penghasilan ini sudah melebihi nishab dengan asumsi Rp 590.000 dikalikan 85 gram emas yaitu Rp 50.150.000, zakatnya dihitung 2,5\% yakni sebesar Rp 1.260.000. Jadi, potensi zakat yang terhimpun dari kaum muslim milenial dalam satu tahun berjumlah yakni sebesar Rp 10.080.000.000.000 (10 triliun).

Data dari Badan Amil Zakat Nasional (BAZNAS) dari total 200 ribu muzakki jumlah milenial yang melakukan transaksi sebesar 40 persennya. Oleh karenanya BAZNAS melakukan digitalisasi fundraising zakat. Oleh karenanya muslim milenial ini menjadi kalangan yang potensial untuk dibidik menjadi muzaki. ${ }^{20}$

Kontribusi muslim milenial dalam gerakan ekonomi Islam di Indonesia tidak diragukan lagi, mereka berkontribusi dalam pengembangan lembaga keuangan syariah. Mereka menjadi nasabah di bank syariah, muzaki di berbagai lembaga zakat. Selain itu mereka juga berkontribusi menjadi SDM yang profesional di berbagai lembaga keuangan syariah.

\section{KESIMPULAN}

Peran muslim milenial Indonesia dalam gerakan ekonomi Islam sangat penting keunggulan mereka menguasai teknologi sehingga ketika mereka bekerja di lembaga keuangan syariah selain mereka menjadi pegawai mereka juga sebagai marketing ekonomi Islam yang menyebarluaskan pentingnya ekonomi Islam. Peran tersebut juga menjadi kontribusi mereka dalam gerakan ekonomi Islam. Mereka telah memenuhi telah memenuhi kebutuhan SDM di lembaga keuangan syariah di Indonesia.

Berdasarkan kesimpulan tersebut maka sangat relevan dengan prediksi dan teori yang dikemukakan para ahli tentang bonus demografi Indonesia yang sedang terjadi saat ini dan yang akan datang. Sehingga gerakan ekonomi Islam akan

${ }^{19}$ Kompas.com. edisi 27 November 2019. KPR Syariah Makin Diminati Milenial Apa Sebabnya. Diakses 20.49 WIB.

${ }^{20}$ Data dari Baznas.go.id. Https://Pid.Baznas.Go.Id/Wp-Content/Uploads/2019/02/Statistik-ZakatNasional-2017.Pdf 
menemukan momentum ketika muslim milenial menjadi motor penggerak ekonomi Islam di Indonesia.

\section{REFERENSI:}

Abdillah, Masykuri. (2011). Islam dan Dinamika Sosial Politik di Indonesia. Jakarta : PT. Gramedia Pustaka Utama

Al-Qaradhawi, Yusuf. (2005). Spektrum Zakat Dalam Membangun Ekonomi Kerakyatan. Jakarta : Zikrul Hakim.

Amalia, Euis. (2010). Peta Potensi SDM Ekonomi Islam pada PTAI dan PTU Analisi Kurikulum, Model Pembelajaran dan Hubungannya dengan Kebutuhan SDM pada Industri Keuangan Syariah. IPIEF, Fakults Ekonomi UMY, Yogyakarta.

Amalia, Euis. (2008). Kadilan Distributif dalam Ekonomi Islam: Penguatan Peran LKM dan UKM di Indoensia. Jakarta: Rajagrafindo.

Azra, Azyumardi. (2000). Pendidikan Islam Tradisi dan Modernisasi Menuju Milenium Baru. Jakarta: PT. Logos Wacana Ilmu.

Chapra, Umer,. (2014). The Future of Economics an Islamic Perspektive, Islmic Foundation.

Faealy, Greg \& White, Sally. (2008). Expressing Islam: religion life and politics in Indonesia Singapore: ISEAS Publishing Institute of Southeast Asian Studies.

Islamic Development Bank. (2016). Forging a Better Future, Togeher Selected recent Success Stories, IDB.

Mannan. Muhammad Abdul (1984). Islamic Economics; Theory and Practice, Delhi.Sh. M. Ashraf, 1070.

Mannan. Muhammad Abdul. (1984). The Making of Islamic Economic Society: Islamic Dimensions in Economic Anallysis. Turky: International Assosiation of Islamic Bank, and International Institute for Islamic Banking and Economic.

Meenai, A. Said. (1984). The Islamic Bank: A Case Study of Islam Cooperation (New York: Kegan Paul International.

Metwally, MM. (1995). Teori dan Model Ekonomi Islam. Jakarta: Bangkit Daya Insana.

Naqvi Syed Nawab Haider (1985). Etika dan Ilmu Ekonomi: Suatu Sintesis Islami. Bandung: Mizan.

Nazir, Moh. (2003). Metode Penelitian. Jakarta: Ghalia Indonesia 2003

Obaiullah, Mohammed. (2003). Financial Contracting in Currency Markets: An Islamic Evaluation. Kuala Lumpur: International Journal of Islamic Financial Services.

Rahardjo, M. Dawam. (1999). Islam dan Transformasi Sosial Ekonomi. Jakarta: LSAF.

Siddiqi, N. Muhammad. (1981). Muslim Economic Thinking: A Survey of Contemporary Literature. Jeddah and The Islamic Foundation. 
Nurhidayat

Tim Kementerian Pemberdayaan Perempuan dan Perlindungan Anak Dengan Pusat Statistik. (2018). Statistik Gender Tematik: Profil Generasi Milenial Indonesia. Kementerian Pemberdayaan Perempuan dan Perlindungan Anak.

Zaman, Hasanuz, S.M. (1991). Economic Function of an Islamic State. Journal of King Abdulaziz University-Islamic Economics. 